THE FAIREST OF THEM ALL 



\section{THE FAIREST \\ OF THEM ALL}

SNOW WHITE

AND 21 TALES OF

MOTHERS AND

DAUGHTERS

MARIA TATAR

The Belknap Press of

Harvard University Press

Cambridge, Massachusetts

London, England

$2 \mathrm{O} 2 \mathrm{O}$ 
Copyright (C) 2020 by Maria Tatar

All rights reserved

Printed in the United States of America

First printing

$$
\begin{gathered}
9780674245808 \text { (EPUB) } \\
9780674245815 \text { (MOBI) } \\
9780674245822 \text { (PDF) }
\end{gathered}
$$

The Library of Congress has cataloged the printed edition as follows:

Names: Tatar, Maria, 1945- author.

Title: The fairest of them all : Snow White and 21 tales of mothers and daughters / Maria Tatar.

Description: Cambridge, Massachusetts : The Belknap Press of Harvard University Press, 2020. | Includes bibliographical references. Identifiers: LCCN 2019041841 | ISBN 9780674238602 (hardcover) Subjects: LCSH: Snow White (Tale) | Mothers and daughters in literature. | Mothers and daughters-Fiction. | LCGFT: Fairy tales. Classification: LCC GR75.S6 T37 2020 | DDC 398.2 [Fic]—dc23

LC record available at https://lccn.loc.gov/2019041841 
FOR BOOKER, ISABEL, AND ROXY 
